\title{
A 2018/2019. évi légúti szezonban influenzaszerü betegséggel kórházban ellátott felnőtt betegek klinikai és mikrobiológiai jellemzése
}

\author{
Laky Boglárka oh. ${ }^{1}$ - Szabó Bálint Gergely dr. ${ }^{2,3}$ \\ ${ }^{1}$ Semmelweis Egyetem, Általános Orvostudományi Kar, Budapest \\ ${ }^{2}$ Dél-pesti Centrumkórház, Országos Hematológiai és Infektológiai Intézet, Budapest \\ ${ }^{3}$ Semmelweis Egyetem, Klinikai Tudományok Doktori Iskola, Budapest
}

Bevezetés, célkitüzés: Az influenzaszezonban fellépő, elsősorban virális megbetegedések jelentős morbiditási és mortalitási teherrel rendelkeznek. Célunk volt az influenzaszerú betegséggel (ILI) és akut légúti betegséggel (ARI) kórházba felvett felnőtt betegek mikrobiológiai és klinikai karakterisztikájának leírása.

Módszerek: Egycentrumos, obszervációs kohorszvizsgálatunk során a 2018/2019. évi légúti szezonban a Dél-pesti Centrumkórház - Országos Hematológiai és Infektológiai Intézet Infektológiai Osztályára ILI/ARI diagnózissal felvett betegek eseteit dolgoztuk fel a kórház elektronikus adatbázisának segítségével. Bevonásra azon betegek kerültek, akiknél légúti PCR-vizsgálat történt. A bevont betegeket alcsoportokra osztottuk: klinikai ILI/ARI, PCR-pozitív ILI/ARI influezavírussal, PCR-pozitív ILI/ARI más vírussal. Elsődleges kimenetelnek a komplikált betegséglefolyást, másodlagos kimenetelnek a kórházi összhalálozást, az intenzív osztályos (ICU-) felvételt, az osztályos ápolás hosszát (LOS) és az ICU LOS-t választottuk. Statisztikai összehasonlításra a Mann-Whitney-féle U-próbát, a Fisherféle egzakt tesztet használtuk.

Eredmények: A bevont 112 eset 42,8\%-ában igazolódott influenza A-vagy B-vírus, 7,1\%-ban egyéb légúti vírus, második leggyakrabban az RSV etiológiai szerepe. Megelőző kórházi ellátás szignifikánsan gyakrabban fordult elő PCRpozitív ILI/ARI esetekben $(23,2 \%$ vs. $42,8 \%$; p = 0,04); ugyanezen betegek körében a panaszok kezdetétól a diagnózisig eltelt idő $\mathrm{kb}$. I nappal rövidebb volt $(3,0 \pm 4,0$ vs. 4,0 $\pm 5,0$ nap; $\mathrm{p}=0,02)$. A komplikációk gyakoriságát hasonló nagyságúnak találtuk $(46,4 \%$ vs. $51,8 \% ; \mathrm{p}=0,72)$, a leggyakoribb szövődmény a tüdőgyulladás volt $(45,5 \%)$. ICU-felvételre az esetek 5,4\%-ában volt szükség, a kórházi összhalálozás 3,6\%-nak adódott. A medián LOS 8,5 \pm 8,0 nap, a medián ICU LOS ideje 20,5 $\pm 30,5$ nap volt.

Következtetés: A vizsgált légúti szezonban ILI/ARI diagnózissal felvett betegek jelentős részében influenza-, kisebb hányadban egyéb légúti vírusok voltak felelősek a klinikumért. A leggyakoribb szövődmény a pneumonia volt. A légúti PCR-vizsgálat lehetőséget nyújthat az etiológia tisztázására.

Orv Hetil. 2020; 161(52): 2179-2187.

Kulcsszavak: influenza, influenzaszerű megbetegedés, akut légúti infekció, járvány, tüdőgyulladás

\section{Differences in characteristics of adult patients hospitalized with influenza-like illness during the $2018 / 2019 \mathrm{flu}$ season}

Introduction, objectives: A significant burden of morbidity and mortality is caused by seasonal outbreaks of respiratory viruses. Our aim was to identify clinical and microbiological differences among adult patients hospitalized with acute respiratory infection (ARI) or influenza-like illness (ILI).

Methods: A single-center observational cohort study was conducted at South Pest Central Hospital, National Institute of Hematology and Infectious Diseases during the 2018/2019 influenza season. Patients were identified using the hospital database, and included in the study if respiratory PCR sampling was done during hospital stay. Subgroups were created according to the identified etiology: clinical ILI/ARI (no PCR positivity), PCR positive ILI/ARI with influenza, PCR positive ILI/ARI with other virus(es). Primary outcome was the occurrence of any complication, secondary outcomes were in-hospital all-cause mortality, intensive care unit (ICU) admission, length of stay (LOS) and ICU LOS. For statistical analysis, Mann-Whitney and Fisher's tests were used.

Results: From 112 identified cases, 42.8\% were caused by influenza A or B, 7.1\% by other viruses, notably RSV. PCR positivity frequently associated with prior hospitalization $(23.2 \%$ vs. $42.8 \%$; $=0.04)$, and shorter time from symp- 
tom onset to diagnosis $(3.0 \pm 4.0$ vs. $4.0 \pm 5.0$ days, $\mathrm{p}=0.02)$. Complication rates were similar among subgroups $(46.4 \%$ vs. $51.8 \% ; \mathrm{p}=0.72)$, with pneumonia as a leading complication $(45.5 \%)$. ICU admission was necessary in $5.4 \%$, in-hospital all-cause mortality was 3.6\%. Median LOS and ICU LOS were $8.5 \pm 8.0$ and $20.5 \pm 30.5$ days, respectively.

Conclusion: During the 2018/2019 season, most ILI/ARI cases were caused by influenza, but other respiratory viruses could also be detected in lower rates. Pneumonia was the most common complication. Respiratory PCR sampling might provide a feasible way of etiology identification.

Keywords: influenza, influenza-like illness, acute respiratory infection, epidemic, pneumonia

Laky B, Szabó BG. [Differences in characteristics of adult patients hospitalized with influenza-like illness during the 2018/2019 flu season]. Orv Hetil. 2020; 161(52): 2179-2187.

(Beérkezett: 2020. szeptember 21.; elfogadva: 2020. október 21.)

\begin{abstract}
Rövidítések
ARDS $=$ (acute respiratory distress syndrome) akut légzési distressz szindróma; ARI $=($ acute respiratory infection $)$ akut légúti infekció; $\mathrm{BAL}=$ bronchoalveolaris lavage $\mathrm{CK}=($ creatine kinase) kreatin-kináz; COPD $=$ (chronic obstructive pulmonary disease) krónikus obstruktív tüdóbetegség; CRP = C-reaktív protein; $\mathrm{CT}=$ (computed tomography) számítógépes tomográfia; DALY = (disability-adjusted life year $)$ egészségkárosodással korrigált életév; ECDC $=($ European Centre for Disease Prevention and Control) Európai Betegségmegelőzési és Járványvédelmi Központ; HMPV = humán metapneumovírus; ICU = (intensive care unit) intenzív terápiás osztály; IKEB = Intézményi Kutatásetikai Bizottság; ILI = (influenza-like illness) influenzaszerû megbetegedés; IQR = (interquartile range) interkvartilis tartomány; $\mathrm{LDH}=$ laktátdehidrogenáz; LOS = (length of stay) a kórházi ellátás időtartama; MALDI$\mathrm{TOF} / \mathrm{MS}=$ ( matrix-assisted laser desorption/ionization-timeof-flight mass spectrometry) mátrixasszisztált lézer deszorpciós/ionizációs, a repülési idő mérésén alapuló tömegspektrometria; PCR $=$ (polymerase chain reaction $)$ polimeráz-láncreakció; RSV = (respiratory syncytial virus) légúti óriássejtes vírus; TSS $=$ (toxic shock syndrome) toxikus sokk szindróma; $\mathrm{WHO}=($ World Health Organization $)$ Egészségügyi Világszervezet
\end{abstract}

Az akut légúti infekció (acute respiratory infection, ARI) a leggyakoribb fertőző betegségek között szerepel világszerte. 2013-ban az Egészségügyi Világszervezet (World Health Organization, WHO) által szponzorált Global Burden Study a fertőző betegségek fó okaként határozta meg az ARI-kat. Ezek kb. 120 millió, egészségkárosodással korrigált életévért (disability-adjusted life year, DALY) felelősek, valamint a 10 leggyakoribb halálozási ok között szerepelnek a 2016. évi mortalitási rangsorban. A különböző légúti etiopatogének által okozott fertőzések általában hasonló tünetekkel jelentkezhetnek, precíz elkülönítésre a molekuláris mikrobiológiai diagnosztika ad lehetőséget $[1,2]$. A szezonális influenzaepidémiák évente kb. 3-5 millió súlyos megbetegedésért, illetve kb. 290 000-650 000 halálesetért felelősek $[3,4]$. Emellett jelentős terhet rónak a társadalomra, hiszen az egészségügyi költségek mellett az életminőség romlása az egyéneket is érinti a munkahelyről, iskolákból való hiányzás tekintetében is [5]. Egy korábbi vizsgálat során kiszámolták, hogy az influenza önmagában évente az USA-ban 1-3 billió USD költséggel terheli az egészségügyet, továbbá 10-15 billió USD veszteség következik az indirekt költségekből [6].

Jelen vizsgálatunk célja volt, hogy bemutassuk a 2018/2019. évi légúti szezon során influenzaszerú megbetegedéssel (ILI, influenza-like illness) és ARI-val kórházi osztályra felvett felnőtt betegek klinikai és mikrobiológiai karakterisztikáját, különösképpen az előforduló szövődményekre nézve. A téma egyik jelentőségét az adja, hogy az ILI-kkel kapcsolatos szezonális adatok a nemzetközi irodalomban bár fellelhetők, a betegek klinikai karakterisztikáját részletesebben vizsgáló hazai tanulmány igen csekély számban található az irodalomban.

\section{Módszerek}

\section{A vizsgálat elrendezése, a betegek azonositása és beválasztása}

Egycentrumos, obszervációs kohorszvizsgálatot végeztünk a Dél-pesti Centrumkórház - Országos Hematológiai és Infektológiai Intézet Infektológiai Osztályán. Vizsgálatunk során prospektíven azonosítottuk azon felnőtt fekvő betegeket, akiket a 2018. október l-től 2019. május 10-ig terjedő szezonban ARI vagy ILI (a definíciókat ld. késóbb) klinikuma miatt hospitalizáltak. A vizsgálat során betartottuk a Helsinki Deklaráció ajánlásait, a vizsgálati protokollt az intézeti etikai bizottság engedélyezte (IKEB/37/2016).

A fenti kritérium mentén valamennyi, potenciálisan beválasztható beteg esetét egyesével, retrospektíven értékeltük a beválasztási torzítás elkerülése végett. Minden azonosított beteg beválasztásra került, ha klinikai esetük ILI-nek vagy ARI-nak megfelelt, és betegségük alatt légúti váladékból (oro-, nasopharyngealis törlet, köpet, egyéb mély légúti minta) a fertőzés etiológiájának igazolására szolgáló PCR-vizsgálat történt legalább egyszer. A priori kizárási kritérium volt, ha a beteg esete vagy 
adatai elérhetetlenek voltak az elektronikus rendszerben, áttekintés alapján a klinikai esetük nem felelt meg ILInek, vagy légúti PCR nem történt a kórházi ellátás során.

\section{Adatok gyüjtése és utánkövetés}

A bevont betegek eseteit a kórházi elektronikus adatbázis segítségével tekintettük át, majd a protokollban meghatározott adatokat anonimizált módon, a vizsgálatvezető által standardizált táblázatba, manuális módszerrel gyưjtöttük. A kórházi elektronikus archiválórendszerbe a betegek ellátásával kapcsolatos információk prospektíven, naponta kerülnek rögzítésre. Utánkövetést az elbocsátást követő időszakban, a legutolsó dokumentált kórházi megjelenésig végeztünk, kizárólag az elektronikus rendszer használatával.

A betegekkel kapcsolatos következő adatok kerültek gyüjtésre: 1) demográfiai adatok (diagnóziskori kor és nem); 2) epidemiológiai adatok (gyermekkontaktus, a betegség kezdetének helye); 3 ) alapbetegségek és egyéb rizikófaktorok (esszenciális hypertonia, krónikus szív-, tüdő-, máj-, vese-, bél-, cerebralis betegség, obesitas, diabetes mellitus, aktív onkohematológiai malignitás, immunszupprimált állapotok, terhesség, előzetes hospitalizáció, szezonális influenza elleni vakcinációs status); 4) a betegség kezdetének és klinikai lefolyásának jellegzetességei (a tünetek kezdetének ideje, a beteg panaszai [láz, arthralgia, myalgia, fejfájás, száraz köhögés, köpetürítés, torokfájás, gyengeség, hasmenés, hányás, dyspnoe, mellkasi fájdalom, tudatzavar); 5 ) labor- (szérumfehérvérsejtszám, CRP, LDH, CK, prokalcitonin, -laktát, -kreatinin), képalkotó (mellkasi röntgenvizsgálat és mellkasi CT) és mikrobiológiai (hemokultúra, légúti PCR, vizelet Legionella sp. és Pneumococcus antigén vizsgálat, köpet vagy bronchoalveolaris lavage [BAL], mini-BAL tenyésztése) vizsgálatok eredményei; 6) intra- és extrathoracalis szövődmények, a kórházi ellátás időtartama (LOS), intenzív osztályos (ICU-) felvétel és az intenzív osztályos ellátás időtartama (ICU LOS); 7) az antimikrobiális terápia jellemzői (időtartam, típus, indikáció); 8) klinikai kimenetelek és az utánkövetés eredményei. Utánkövetésre a kórházi elektronikus rendszert használtuk, az elbocsátást követően a legutolsó elérhető ambuláns vagy fekvő megjelenésig.

\section{A vizsgálat során használt esetdefiniciók}

Vizsgálatunk során az Európai Betegségmegelőzési és Járványvédelmi Központ (European Centre for Disease Prevention and Control, ECDC) esetdefinícióit alkalmaztuk [7]. ILI-ként definiáltuk, ha hirtelen tünetkezdet mellett legalább egy szisztémás tünet jelen volt a következő négyből: 1) láz; 2 ) gyengeség, rossz közérzet; 3 ) fejfájás; 4) izomfájdalom, valamint legalább egy légúti tünet a következő háromból: 1) köhögés; 2) torokfájás; $3)$ nehézlégzés. ARI-ként definiáltuk, ha hirtelen tünetkezdet mellett legalább egy légúti tünet teljesült a követ- kező négyből: 1 ) köhögés; 2 ) torokfájás; 3 ) nehézlégzés; 4) nátha (orrfolyás, orrdugulás), és a klinikum hátterében fertőzés volt valószínúsíthető.

Bizonyított influenza eseteként definiáltuk, ha klinikai ILI vagy ARI (ILI/ARI) diagnózisa mellett spontán légző betegnél az orr- és szájgaratból, intubált betegnél a mély légútból (BAL, mini-BAL) származó mintán végzett PCR-vizsgálat influenza A- és/vagy influenza B-vírus jelenlétét bizonyította. Amennyiben az ILI/ARI klinikai képének hátterében PCR-rel vagy egyéb mikrobiológiai módszerrel más közösségben szerzett légúti vírus vagy baktérium kórokozó szerepe validált, ILI/ARI diagnózisát állítottuk fel az adott etiológia megnevezésével. Amennyiben az ILI/ARI klinikai képének hátterében az adott klinikumot előidézni képes, közösségben szerzett légúti vírus vagy baktérium nem volt kimutatható PCR-rel vagy más mikrobiológiai módszerrel (ld. később), az etiológia további meghatározása nélkül a klinikai ILI/ARI diagnózisát állítottuk fel.

\section{Diagnosztikai háttér}

A mikrobiológiai vizsgálatokat minden esetben frissen gyưjiött klinikai mintából, kórházunk saját mikrobiológiai és virológiai laboratóriumában végezték. A minták tenyésztése során izolált baktériumok identifikálása a hagyományos biokémiai eljárások mellett MALDI-TOF/ MS-módszerrel történik. Hemokultúrákat lázas, valamint szeptikus betegektől rutinszerüen vesznek kórházunkban, a vizelet Pneumococcus és Legionella sp. antigén teszt végzése radiológiailag is pneumonia esetén történik. Molekuláris diagnosztikára a Seegene (Szöul, Koreai Köztársaság) Allplex és a BioFire (Salt Lake City, UT, USA) FilmArray multiplex légúti PCR-kitjeit alkalmaztuk (elérhetőség szerint). A tesztek rendelése és elvégzése a beteget ellátó klinikus döntése alapján történt.

\section{Klinikai kimenetelek}

Elsődleges kimenetelnek a komplikált betegséglefolyást választottuk. Komplikált betegséglefolyásként definiáltuk, ha a kórházi ellátás során olyan új keletű szervi diszfunkciót detektáltunk, melynek létrejötte az akut légúti fertőzéssel összefüggésbe hozható volt. Komplikációnak tekintettük a következő állapotokat: pneumonia, rhabdomyolysis, myocarditis, encephalitis, akut légzési distressz szindróma (acute respiratory distress syndrome, ARDS), szepszis, toxikus sokk szindróma (toxic shock syndrome, TSS). Másodlagos kimeneteli végpontoknak a kórházi összhalálozást, az intenzív osztályos felvétel arányát, a LOS-t és az ICU LOS-t választottuk.

\section{Statisztikai analizis}

A folytonos változókat medián \pm interkvartilis tartomány (IQR), valamint minimum-maximum (min.-max.) 
1. táblázat | A 2018/2019. évi influenzaszezonban ILI/ARI miatt hospitalizált felnőtt betegek kohorszának demográfiai és klinikai karakterisztikája, PCR-pozitivitás szerinti alcsoportokban

\begin{tabular}{|c|c|c|c|c|c|}
\hline \multirow[t]{2}{*}{ Paraméter } & \multirow{2}{*}{$\begin{array}{l}\text { Kohorsz } \\
(\mathrm{n}=112)\end{array}$} & \multirow{2}{*}{$\begin{array}{l}\text { Klinikai ILI } / \text { ARI }^{1} \\
\quad(\mathrm{n}=56)\end{array}$} & \multicolumn{2}{|c|}{ PCR-pozitív ILI/ARI ( $\mathrm{n}=56$ ) } & \multirow[t]{2}{*}{ p-érték } \\
\hline & & & Influenza $(\mathrm{n}=48)$ & Egyéb vírus $(\mathrm{n}=8)$ & \\
\hline $\begin{array}{l}\text { Életkor } \\
\text { (év, medián } \pm \mathrm{IQR} \text {, min.- }- \text { max.) }\end{array}$ & $\begin{array}{l}48,5 \pm 29,3 \\
\quad(19-89)\end{array}$ & $\begin{array}{l}46,3 \pm 33,6 \\
\quad(19-87)\end{array}$ & $\begin{array}{l}48,5 \pm 29,3 \\
(19-89)\end{array}$ & $\begin{array}{l}45,4 \pm 30,5 \\
\quad(29-82)\end{array}$ & 0,58 \\
\hline Férfinem (n, \%) & $51(45,5 \%)$ & $21(37,5 \%)$ & $25(52,1 \%)$ & $5(62,5)$ & 0,12 \\
\hline $\begin{array}{l}\text { Komorbiditások (n, \%): } \\
\text { - Esszenciális hypertonia } \\
\text { - Krónikus szívbetegség } \\
\text { - Krónikus tüdőbetegség } \\
\text { - Krónikus májbetegség } \\
\text { - Krónikus gyomor-bél betegség } \\
\text { - Krónikus vesebetegség } \\
\text { - Krónikus cerebralis betegség } \\
\text { - Krónikus immunszupprimált állapot } \\
\text { - Aktív onkohematológiai malignitás } \\
\text { - Cukorbetegség }\end{array}$ & $\begin{array}{l}35(31,3 \%) \\
24(21,4 \%) \\
10(8,9 \%) \\
12(10,7 \%) \\
8(7,1 \%) \\
14(12,5 \%) \\
15(13,4 \%) \\
30(26,8 \%) \\
10(8,9 \%) \\
13(11,6 \%)\end{array}$ & $\begin{aligned} 14 & (25 \%) \\
15 & (26,8 \%) \\
5 & (8,9 \%) \\
5 & (8,9 \%) \\
5 & (8,9 \%) \\
6 & (10,7 \%) \\
5 & (8,9 \%) \\
14 & (25 \%) \\
5 & (8,9 \%) \\
8 & (14,3 \%)\end{aligned}$ & $\begin{aligned} 18 & (37,5 \%) \\
7 & (14,6 \%) \\
5 & (10,4 \%) \\
7 & (14,6 \%) \\
2 & (4,2 \%) \\
6 & (12,5 \%) \\
9 & (18,8 \%) \\
13 & (27,1 \%) \\
3 & (6,3 \%) \\
5 & (10,4 \%)\end{aligned}$ & $\begin{array}{l}3(37,5 \%) \\
2(25,0 \%) \\
0 \\
0 \\
1(12,5 \%) \\
2(25 \%) \\
1(12,5 \%) \\
3(37,5 \%) \\
2(25 \%) \\
0\end{array}$ & $\begin{array}{l}0,22 \\
0,29 \\
1,0 \\
0,76 \\
0,71 \\
0,77 \\
0,26 \\
0,83 \\
1,0 \\
0,55\end{array}$ \\
\hline $\begin{array}{l}\text { Az influenza egyéb rizikófaktorai ( } \mathrm{n}, \%) \text { : } \\
\text { - Életkor> } 65 \text { év } \\
\text { - Terhesség } \\
\text { - Recens hospitalizácó } \\
\text { - Obesitas }\end{array}$ & $\begin{array}{c}29(25,9 \%) \\
0 \\
37(33 \%) \\
11(9,8 \%)\end{array}$ & $\begin{array}{l}14(25 \%) \\
0 \\
13(23,2 \%) \\
5(8,9 \%)\end{array}$ & $\begin{array}{r}13(27,1 \%) \\
0 \\
22(45,8 \%) \\
6(12,5 \%)\end{array}$ & $\begin{array}{l}2(25 \%) \\
0 \\
2(25 \%) \\
0\end{array}$ & $\begin{array}{l}1,0 \\
\text { n.a. } \\
0,04 \\
1,0\end{array}$ \\
\hline $\begin{array}{l}\text { A felvétel iránya (n, \%): } \\
\text { - Közösségbőll } \\
\text { - Szociális otthonból } \\
\text { - Más kórházból }\end{array}$ & $\begin{aligned} 85 & (75,9 \%) \\
3 & (2,7 \%) \\
20 & (17,9 \%)\end{aligned}$ & $\begin{array}{l}46(82,1 \%) \\
0 \\
9(16,1 \%)\end{array}$ & $\begin{array}{c}35(72,9 \%) \\
3(6,3 \%) \\
9(18,8 \%)\end{array}$ & $\begin{array}{l}4(50 \%) \\
0 \\
2(25 \%)\end{array}$ & $\begin{array}{l}0,06 \\
0,24 \\
0,80\end{array}$ \\
\hline Explorálható gyermekkontant (n, \%) & $12(10,7 \%)$ & $7(12,5 \%)$ & $5(10,4 \%)$ & 0 & 0,76 \\
\hline $\begin{array}{l}\text { A panaszok kezdetétől a diagnózisig } \\
\text { eltelt idő } \\
\text { (nap, medián } \pm \mathrm{IQR}, \min .-\mathrm{max} .)\end{array}$ & $\begin{array}{l}3,5 \pm 4,5 \\
(0-30)\end{array}$ & $\begin{array}{l}4,0 \pm 5,0 \\
(0-30)\end{array}$ & $\begin{array}{c}3,0 \pm 3,8 \\
(0-30)\end{array}$ & $\begin{array}{l}2,0 \pm 1,0 \\
(0-14)\end{array}$ & 0,02 \\
\hline $\begin{array}{l}\text { Klinikai tünetek a diagnóziskor (n, \%): } \\
\text { - Láz } \\
\text { - Fejfájás } \\
\text { - Arthralgia/myalgia } \\
\text { - Orrfolyás } \\
\text { - Köhögés } \\
\text { - Köpetürítés } \\
\text { - Torokfájás } \\
\text { - Gyengeség } \\
\text { - Hasmenés } \\
\text { - Hányinger, hányás } \\
\text { - Dyspnoe } \\
\text { - Zavartság } \\
\text { - Mellkasi fájdalom }\end{array}$ & $\begin{array}{l}95(84,8 \%) \\
28(25 \%) \\
25(22,3 \%) \\
25(22,3 \%) \\
84(75 \%) \\
27(24,1 \%) \\
15(13,4 \%) \\
38(33,9 \%) \\
20(17,9 \%) \\
27(33,0 \%) \\
26(23,2 \%) \\
3(2,7 \%) \\
9(8,0 \%)\end{array}$ & $\begin{array}{c}46(82,1 \%) \\
17(30,4 \%) \\
13(23,2 \%) \\
14(25,0 \%) \\
40(71,4 \%) \\
15(26,8 \%) \\
11(19,6 \%) \\
21(37,5 \%) \\
8(14,3 \%) \\
21(37,5 \%) \\
11(19,6 \%) \\
2(3,6 \%) \\
4(7,1 \%)\end{array}$ & $\begin{aligned} & 44(91,7 \%) \\
& 10(20,8 \%) \\
& 12(25,0 \%) \\
& 9(18,8 \%) \\
& 41(85,4 \%) \\
& 12(25,0 \%) \\
& 3(6,3 \%) \\
& 15(31,3 \%) \\
& 11(22,9 \%) \\
& 14(29,2 \%) \\
& 12(25,0 \%) \\
& 1(2,1 \%) \\
& 5(10,4 \%)\end{aligned}$ & $\begin{array}{l}5(62,5 \%) \\
1(12,5 \%) \\
0 \\
2(25 \%) \\
3(37,5 \%) \\
1(12,5 \%) \\
2(25 \%) \\
2(25 \%) \\
1(12,1 \%) \\
2(25 \%) \\
3(37,5 \%) \\
0 \\
0\end{array}$ & $\begin{array}{l}0,59 \\
0,27 \\
0,65 \\
0,65 \\
0,51 \\
0,82 \\
0,17 \\
0,54 \\
0,8 \\
0,42 \\
0,5 \\
1,0 \\
1,0\end{array}$ \\
\hline $\begin{array}{l}\text { Laboreltérések (medián } \pm \text { IQR, } \\
\text { min.--max.): } \\
\text { - Szérum-fehérvérsejtszám }\left(\times 10^{9} / \mathrm{l}\right) \\
\text { - CRP }(\mathrm{mg} / \mathrm{l}) \\
\text { - Prokalcitonin }(\mathrm{ng} / \mathrm{ml}) \\
\text { - Szérumlaktát }(\mathrm{mmol} / \mathrm{l}) \\
\text { - LDH }(\mathrm{IU} / \mathrm{l}) \\
\text { - CK }(\mathrm{IU} / \mathrm{l}) \\
\text { - Szérumkreatinin }(\mu \mathrm{mol} / \mathrm{l})\end{array}$ & $\begin{array}{c}8,1 \pm 7,1(2-40,6) \\
59 \pm 111(1-370) \\
0,3 \pm 0,3(0,1-42,9) \\
2,7 \pm 1,2(1,2-4,7) \\
391 \pm 187(68-1463) \\
84 \pm 101(5-1886) \\
73 \pm 34(25-489)\end{array}$ & $\begin{array}{c}9,5 \pm 7,5(2-40,6) \\
95 \pm 136(1-370) \\
0,3 \pm 0,4(0,1-42,9) \\
2,7 \pm 1,0(1,2-4,7) \\
377 \pm 162(232-1463) \\
62 \pm 69(5-931) \\
68 \pm 31(25-247)\end{array}$ & $\begin{array}{c}6,7 \pm 5,3(2,4-18,8) \\
40 \pm 66(1-312) \\
0,2 \pm 0,4(0,1-18,0) \\
2,7 \pm 1,3(1,5-4,6) \\
432 \pm 182(68-976) \\
125 \pm 154(7-1886) \\
85 \pm 36(25-487)\end{array}$ & $\begin{array}{c}6,9 \pm 2,6(4,6-10,2) \\
115 \pm 91(6-237) \\
0,3 \pm 0,2(0,1-0,5) \\
3,1 \pm 1,2(1,9-4,3) \\
925 \pm 394(482-1271) \\
54 \pm 13(42-67) \\
59 \pm 19(40-102)\end{array}$ & $\begin{array}{l}0,03 \\
0,27 \\
0,08 \\
0,5 \\
0,11 \\
0,01 \\
0,07\end{array}$ \\
\hline $\begin{array}{l}\text { Képalkotó eltérések (n, \%): } \\
\text { - Mellkasi röntgen készült } \\
\text { - Mellkasi röntgenen eltérés ábrázolódott } \\
\text { - Mellkasi CT készült } \\
\text { - Mellkasi CT-n eltérés ábrázolódott }\end{array}$ & $\begin{array}{c}105(93,8 \%) \\
60(53,6 \%) \\
10(8,9 \%) \\
9(8,0 \%)\end{array}$ & $\begin{array}{r}52(92,9 \%) \\
29(51,8 \%) \\
7(12,5 \%) \\
6(10,7 \%)\end{array}$ & $\begin{array}{c}45(93,8 \%) \\
24(50 \%) \\
2(4,2 \%) \\
2(4,2 \%)\end{array}$ & $\begin{array}{l}8(100 \%) \\
7(87,5 \%) \\
1(12,5 \%) \\
1(12,5 \%)\end{array}$ & $\begin{array}{l}1,0 \\
0,84 \\
0,32 \\
0,48\end{array}$ \\
\hline
\end{tabular}

${ }^{1}$ Légúti PCR-vizsgálattal negatív klinikai esetek

${ }^{2}$ Klinikai ILI/ARI vs. PCR-pozitív ILI/ARI alcsoportok között

n.a.: nem alkalmazható

$\mathrm{ARI}=$ akut légúti infekció; $\mathrm{CK}=$ kreatin-kináz; CRP = C-reaktív protein; $\mathrm{CT}$ = számítógépes tomográfia; ILI = influenzaszerû megbetegedés;

IQR = interkvartilis tartomány; LDH = laktátdehidrogenáz; PCR = polimeráz-láncreakció 
értékekkel, a diszkrét változókat az abszolút értékek (n) és a relatív arányok (\%) feltüntetésével adjuk meg. Statisztikai összehasonlításra a Mann-Whitney-féle U-próbát és a Fisher-féle egzakt tesztet használtuk. Statisztikai szignifikanciáról kétvégű p-érték <0,05 mellett döntöttünk. Analíziseinket a GraphPad (San Diego, CA, USA) Prism 5.0 szoftverével végeztük.

\section{Eredmények}

\section{Demográfiai és klinikai karakterisztika}

A 2018/2019. évi légúti szezon során 112 konszekutív beteg esetét azonosítottuk és vontuk be a vizsgálatba. A betegek demográfiai és klinikai karakterisztikáját az 1. táblázat szemlélteti. A medián életkor 48,5 \pm 29,3 évnek adódott, a betegek negyede $(25,9 \%)$ volt 65 év feletti. A nemek aránya közel kiegyenlített volt a kohorszban. A betegek között a legnagyobb arányban cardiovascularis betegségben szenvedők (hypertonia 31,3\%, krónikus szívbetegség 21,4\%) és immunkompromittáltak (26,8\%) voltak, krónikus légúti betegség 10 fónél $(8,9 \%)$ volt jelen a diagnóziskor. Előzetes hospitalizáció szignifikánsan gyakrabban fordult elő PCR-pozitív ILI/ARI esetekben (23,2\% vs. $42,8 \%$; p = 0,04); ugyanezen betegek körében a panaszok kezdetétől a diagnózisig eltelt idő kb. 1 nappal rövidebb volt $(3,0 \pm 4,0$ vs. $4,0 \pm 5,0$ nap, $\mathrm{p}=0,02)$. Szezonális influenza elleni vakcinációban sajnálatos módon egyetlen bevont beteg sem részesült. Az osztályra felvettek többsége közösségből érkezett $(75,9 \%)$, gyermekkel való közeli kontaktus 10,7\%-uknál volt azonosítható. A klinikai tünetek közül a láz $(84,8 \%)$, a száraz köhögés $(50,9 \%)$, az izomfájdalom $(22,3 \%)$, a gyengeség $(33,9 \%)$, a hányinger vagy hányás $(33 \%)$, valamint a nehézlégzés (23\%) dominált. Az egyes alcsoportok között a tünettanban statisztikailag szignifikáns különbség nem mutatkozott, de a később bizonyított influenzás betegek körében a láz $(91,7 \%)$ és a hasmenés $(22,9 \%)$ megléte, valamint a torokfájás hiánya $(6,3 \%)$ tendenciaszerűen magasabb volt. A laboreltérések közül a szérum-fehérvérsejtszám $\left(9,5 \pm 7,5 \times 10^{9} / 1\right.$ vs. $6,8 \pm 4,2 \times 10^{9} / 1, \mathrm{p}=$ $0,03)$ a klinikai ILI/ARI, a CK értéke az influenza (62 \pm $69 \mathrm{IU} / 1$ vs. $121 \pm 154 \mathrm{IU} / 1, \mathrm{p}=0,01)$ csoportjában volt szignifikánsan magasabb. Mellkasi röntgenfelvétel szinte minden betegről $(93,8 \%)$, mellkasi CT a betegek 8,9\%-áról készült; eltérés röntgennel 57,1\%-ban, CT-vel 90,0\%-ban ábrázolódott.

2. táblázat | A 2018/2019. évi influenzaszezonban ILI/ARI miatt hospitalizált felnőtt betegek kohorszának mikrobiológiai karakterisztikája, PCR-pozitivitás szerinti alcsoportokban

\begin{tabular}{|c|c|c|c|c|c|}
\hline \multirow[t]{2}{*}{ Paraméter } & \multirow[t]{2}{*}{$\begin{array}{l}\text { Kohorsz } \\
(\mathrm{n}=112)\end{array}$} & \multirow[t]{2}{*}{$\begin{array}{l}\text { Klinikai ILI/ARI }{ }^{1} \\
\quad(\mathrm{n}=56)\end{array}$} & \multicolumn{2}{|c|}{$\begin{array}{c}\text { PCR-pozitív ILI/ARI } \\
(\mathrm{n}=56)\end{array}$} & \multirow[t]{2}{*}{ p-érték ${ }^{2}$} \\
\hline & & & Influenza $(\mathrm{n}=48)$ & Egyéb vírus $(\mathrm{n}=8)$ & \\
\hline $\begin{array}{l}\text { Hemokultúra }(\mathrm{n}, \%) \text { : } \\
\text { - Vétele történt } \\
\text { - Ebból valós bacteriaemia igazolódott }\end{array}$ & $\begin{array}{c}81(72,3 \%) \\
9(8,0 \%) \\
\end{array}$ & $\begin{array}{r}44(78,6 \%) \\
6(10,7 \%) \\
\end{array}$ & $\begin{array}{c}30(62,5 \%) \\
3(6,3 \%) \\
\end{array}$ & $\begin{array}{l}7(87,5 \%) \\
0\end{array}$ & $\begin{array}{l}0,2 \\
0,48\end{array}$ \\
\hline $\begin{array}{l}\text { Köpet }(\mathrm{n}, \%) \text { : } \\
\text { - Vétele történt } \\
\text { - Ebból mikrobiológiailag pozitív }\end{array}$ & $\begin{array}{l}8(7,1 \%) \\
2(1,8 \%) \\
\end{array}$ & $\begin{array}{l}5(8,9 \%) \\
1(1,8 \%) \\
\end{array}$ & $\begin{array}{l}2(4,2 \%) \\
1(2,1 \%) \\
\end{array}$ & $\begin{array}{l}1(12,5 \%) \\
0\end{array}$ & $\begin{array}{l}0,71 \\
1,0 \\
\end{array}$ \\
\hline $\begin{array}{l}\text { Vizelet-antigénteszt (n, \%): } \\
\text { - Vétele történt } \\
\text { - Ebból mikrobiológiailag pozitív }\end{array}$ & $\begin{array}{l}26(23,2 \%) \\
0\end{array}$ & $\begin{array}{r}17(30,4 \%) \\
0\end{array}$ & $\begin{array}{l}8(16,7 \%) \\
0\end{array}$ & $\begin{array}{l}1(12,5 \%) \\
0\end{array}$ & $\begin{array}{l}0,11 \\
\text { n.a. }\end{array}$ \\
\hline $\begin{array}{l}\text { Azonosított légúti etiopatogének (n, \%): } \\
\text { - Influenza A } \\
\text { - Influenza B } \\
\text { - Humán metapneumovírus } \\
\text { - Rhinovirus } \\
\text { - Respiratory syncytial vírus } \\
\text { - Parainfluenzavírus } \\
\text { - Haemophilus influenzae } \\
\text { - Streptococcus pneumoniae } \\
\text { - Összesen }\end{array}$ & $\begin{aligned} & 47(78,3 \%) \\
& 1(1,7 \%) \\
& 2(3,4 \%) \\
& 1(1,7 \%) \\
& 4(6,7 \%) \\
& 1(1,7 \%) \\
& 2(3,4 \%) \\
& 2(3,4 \%) \\
& 60(100 \%) \\
&\end{aligned}$ & n.a. & $\begin{aligned} & 47(94 \%) \\
& 1(1,9 \%) \\
& 1(1,9 \%) \\
& 0 \\
& 0 \\
& 0 \\
& 1(1,9 \%) \\
& 2(3,8 \%) \\
& 52(100 \%)\end{aligned}$ & $\begin{array}{l}0 \\
0 \\
1(12,5 \%) \\
1(12,5 \%) \\
4(50 \%) \\
1(12,5 \%) \\
1(12,5 \%) \\
0 \\
8(100 \%) \\
\end{array}$ & n.a. \\
\hline $\begin{array}{l}\text { Az azonosított véráram-infekciók etiopatogénjei (n, \%): } \\
\text { - Streptococcus pneumoniae } \\
\text { - Enterococcus faecium } \\
\text { - Haemophilus influenzae } \\
\text { - Escherichia coli } \\
\text { - Klebsiella pneumoniae } \\
\text { - Salmonella sp. } \\
\text { - Összesen }\end{array}$ & $\begin{array}{l}1(11,1 \%) \\
1(11,1 \%) \\
1(11,1 \%) \\
2(22,2 \%) \\
2(22,2 \%) \\
2(22,2 \%) \\
9(100 \%)\end{array}$ & $\begin{array}{l}1(16,7 \%) \\
1(16,7 \%) \\
1(16,7 \%) \\
2(33,3 \%) \\
1(16,7 \%) \\
0 \\
6(100 \%)\end{array}$ & $\begin{array}{l}0 \\
0 \\
0 \\
0 \\
1(33,3 \%) \\
2(66,7 \%) \\
3(100 \%)\end{array}$ & $\begin{array}{l}0 \\
0 \\
0 \\
0 \\
0 \\
0 \\
0\end{array}$ & $\begin{array}{l}\text { n.a. } \\
\text { n.a. } \\
\text { n.a. } \\
\text { n.a. } \\
1,0 \\
\text { n.a. } \\
0,48\end{array}$ \\
\hline
\end{tabular}

${ }^{1}$ Légúti PCR-vizsgálattal negatív klinikai esetek

${ }^{2}$ Klinikai ILI/ARI vs. PCR-pozitív ILI/ARI alcsoportok között

n.a.: nem alkalmazható

$\mathrm{ARI}=$ akut légúti infekció; ILI = influenzaszerû megbetegedés; PCR = polimeráz-láncreakció 


\section{Mikrobiológiai karakterisztika}

A 2. táblázat szemlélteti a bevont betegek mikrobiológiai karakterisztikáját. A klinikai kép hátterében az esetek 50\%-ában igazolódott légúti PCR-pozitivitással etiológia. Az összes pozitív légúti minta 83,9\%-ában volt kimutatható influenza A jelenléte, az influenza B-vírus 1 esetben okozott betegséget a kohorszban (1,7\%). A PCR-pozitív ILI/ARI esetek 50\%-ában humán légúti óriássejtes vírus (RSV) volt az igazolt etiopatogén, ez egyben a kohorsz második leggyakoribb virális etiopatogénje. A zajló légúti klinikumot 2-2 esetben (3,4-3,4\%) Streptococcus pneumoniae, valamint Haemophilus influenzae magyarázta a kohorszban. Hemokultúra vétele 72,3\%-ban, köpettenyésztés 7,1\%-ban, vizeletantigénvizsgálat 26,6\%-ban, mini-BAL pedig az intenzív osztályra felvett betegek mindegyikénél történt. Valós bacteriaemiát 8,0\%-ban detektáltunk a kohorszban, az esetek 66,7\%-a a klinikai ILI/ARI alcsoportban lépett fel. A kohorszban a véráram-infekciókat 1-1 esetben
(1,1-1,1\%) okozza S. pneumoniae és $H$. influenzae (a klasszikus értelemben vett légúti bakteriális kórokozók). Vizeletantigénteszt-pozitivitást nem találtunk, a köpettenyésztés pozitivitási rátája alacsony volt.

\section{Kimeneteli karakterisztika}

A 3. táblázat szemlélteti a klinikai kimeneteleket, a bevezetett antimikrobiális terápiákat, valamint az utánkövetés eredményeit. Komplikációt összességében 49,1\%-ban rögzítettünk az egész kohorszban; a nem influenzával diagnosztizált, PCR-pozitív ILI/ARI esetek körében a szövődményráta trendszerúen magasabb volt (75\%), de statisztikailag szignifikáns különbséget nem találtunk. A leggyakoribb komplikáció a pneumonia volt $(45,5 \%)$, ezt követte a szepszis $(8,0 \%)$, míg néhány esetben ARDS és rhabdomyolysis lépett fel (2,7-2,7\%). A komplikált esetekben előforduló leggyakoribb komorbiditás a krónikus szívbetegség (27\%) és az immunszuppresszió $(27 \%)$ volt. A vezető komorbiditásokban szenvedő bete-

3. táblázat |A 2018/2019. évi influenzaszezonban ILI/ARI miatt hospitalizált felnőtt betegek kohorszának kimenetelei, az utánkövetés eredményei és a bevezetett antimikrobiális terápiák, PCR-pozitivitás szerinti alcsoportokban

\begin{tabular}{|c|c|c|c|c|c|}
\hline \multirow[t]{2}{*}{ Paraméter } & \multirow{2}{*}{$\begin{array}{l}\text { Kohorsz } \\
(\mathrm{n}=112)\end{array}$} & \multirow{2}{*}{$\begin{array}{l}\text { Klinikai ILI } / \text { ARI }^{1} \\
\qquad(\mathrm{n}=56)\end{array}$} & \multicolumn{2}{|c|}{ PCR-pozitív ILI/ARI ( $\mathrm{n}=56)$} & \multirow[t]{2}{*}{ p-érték ${ }^{2}$} \\
\hline & & & Influenza $(\mathrm{n}=48)$ & Egyéb vírus $(\mathrm{n}=8)$ & \\
\hline Szövődmény összesen (n, \%) & $55(49,1 \%)$ & $26(46,4 \%)$ & $23(47,9 \%)$ & $6(75 \%)$ & 0,72 \\
\hline $\begin{array}{l}\text { Szövődmények részletesen }(\mathrm{n}, \%) \text { : } \\
\text { - Pneumonia } \\
\text { - Rhabdomyolysis } \\
\text { - Myocarditis } \\
\text { - Encephalitis } \\
\text { - ARDS } \\
\text { - Szepszis } \\
\text { - TSS }\end{array}$ & $\begin{array}{l}51(45,5 \%) \\
3(2,7 \%) \\
0 \\
0 \\
3(2,7 \%) \\
9(8,0 \%) \\
0\end{array}$ & $\begin{array}{l}24(42,9 \%) \\
2(3,6 \%) \\
0 \\
0 \\
1(1,8 \%) \\
6(10,7 \%) \\
0\end{array}$ & $\begin{array}{l}21(43,8 \%) \\
1(2,1 \%) \\
0 \\
0 \\
1(2,1 \%) \\
2(4,2 \%) \\
0\end{array}$ & $\begin{array}{l}6(75 \%) \\
0 \\
0 \\
0 \\
1(12,5 \%) \\
1(12,5 \%) \\
0\end{array}$ & $\begin{array}{l}0,72 \\
1,0 \\
\text { n.a. } \\
\text { n.a. } \\
1,0 \\
0,48 \\
\text { n.a. }\end{array}$ \\
\hline Kórházi összhalálozás (n, \%) & $4(3,6 \%)$ & $4(7,1 \%)$ & 0 & 0 & n.a. \\
\hline LOS (nap, medián \pm IQR, min.--max.) & $8,5 \pm 8,0(1-85)$ & $7,0 \pm 7,0(2-85)$ & $8,0 \pm 9,0(1-39)$ & $10 \pm 17,5(6-44)$ & 0,46 \\
\hline ICU LOS (nap, medián \pm IQR, min.-max.) & $20,5 \pm 30,5(3-42)$ & $22,5 \pm 19,5(3-42)$ & $37,0 \pm 5,0(32-42)$ & $9,0 \pm 0(9)$ & 1,0 \\
\hline ICU-felvétel $(\mathrm{n}, \%)$ & $6(5,4 \%)$ & $2(3,6 \%)$ & $2(4,2 \%)$ & $2(25 \%)$ & 0,67 \\
\hline Utánkövetési adat elérhető (n, \%) & $61(54,5 \%)$ & $30(53,6 \%)$ & $27(56,3 \%)$ & $4(50 \%)$ & 1,0 \\
\hline $\begin{array}{l}\text { Az utánkövetés során túlélés } \\
\text { (hónap, medián } \pm \mathrm{IQR} \text {, min.-max.) }\end{array}$ & $4,0 \pm 8,0(1-14)$ & $5,5 \pm 9,5(1-14)$ & $4,0 \pm 6,0(1-13)$ & $4,5 \pm 5,3(1-13)$ & 0,56 \\
\hline $\begin{array}{l}\text { Empirikus és célzott antimikrobiális terápia } \\
(\mathrm{n}, \%) \text { : } \\
\text { - Oszeltamivir } \\
\text { - Ceftriaxon } \\
\text { - Meropenem } \\
\text { - Imipenem/cilasztatin } \\
\text { - Piperacillin/tazobaktám } \\
\text { - Moxifloxacin } \\
\text { - Azitromicin } \\
\text { - Klaritromicin } \\
\text { - Vankomicin } \\
\text { - Levofloxacin } \\
\text { - Co-trimoxazol } \\
\text { - Doxiciklin }\end{array}$ & $\begin{array}{c}55(49,1 \%) \\
30(26,8 \%) \\
3(2,7 \%) \\
15(13,4 \%) \\
2(1,8 \%) \\
6(5,4 \%) \\
7(6,3 \%) \\
18(16,1 \%) \\
4(3,6 \%) \\
10(8,9 \%) \\
6(5,4 \%) \\
3(2,7 \%)\end{array}$ & $\begin{array}{c}16(28,6 \%) \\
17(30,4 \%) \\
1(1,8 \%) \\
9(16,1 \%) \\
1(1,8 \%) \\
3(5,4 \%) \\
5(8,9 \%) \\
9(16,1 \%) \\
2(3,6 \%) \\
4(7,1 \%) \\
3(5,4 \%) \\
3(5,4 \%)\end{array}$ & $\begin{array}{c}35(72,9 \%) \\
9(18,8 \%) \\
1(2,1 \%) \\
5(10,4 \%) \\
1(2,1 \%) \\
3(6,3 \%) \\
2(4,2 \%) \\
5(10,4 \%) \\
1(2,1 \%) \\
5(10,4 \%) \\
2(4,2 \%) \\
0\end{array}$ & $\begin{array}{l}4(50 \%) \\
4(50 \%) \\
1(12,5 \%) \\
1(12,5 \%) \\
0 \\
0 \\
0 \\
4(50 \%) \\
1(12,5 \%) \\
1(12,5 \%) \\
1(12,5 \%) \\
0\end{array}$ & $\begin{array}{l}0,001 \\
0,52 \\
1,0 \\
0,58 \\
\text { n.a. } \\
\text { n.a. } \\
\text { n.a. } \\
1,0 \\
1,0 \\
0,74 \\
1,0 \\
0,24\end{array}$ \\
\hline
\end{tabular}

${ }^{1}$ Légúti PCR-vizsgálattal negatív klinikai esetek

${ }^{2}$ Klinikai ILI/ARI vs. PCR-pozitív ILI/ARI alcsoportok között

n.a.: nem alkalmazható

ARDS = akut légzési distressz szindróma; ARI = akut légúti infekció; ICU = intenzív terápiás osztály; ILI = influenzaszerű megbetegedés; IQR = interkvartilis tartomány; LOS = a kórházi ellátás időtartama; PCR = polimeráz-láncreakció; TSS = toxikus sokk szindróma 
gek (krónikus szív-ér rendszeri, tüdő- és vesebetegek, cukorbetegek és aktív malignus betegségben szenvedők) mintegy 40-50\%-ában lépett fel szövődmény. Az osztályos ellátás medián időtartama $8,5 \pm 8,0$ nap volt. Intenzív osztályos felvételre $5,4 \%$-ban volt szükség, az itteni ellátás medián időtartama közel 3 hét volt $(20,5 \pm 30,5$ nap). A kórházi összhalálozást 3,6\%-nak kalkuláltuk az egész kohorszra vetítve, az elhunytak a klinikai ILI/ARI alcsoportjából kerültek ki. A betegek kb. fele utánkövethető volt $(54,5 \%)$, medián $4,0 \pm 8,0$ hónap során kórházi halálozást nem rögzítettünk. Antimikrobiális terápiaként oszeltamivir $(49,1 \%)$ és ceftriaxon $(26,8 \%)$ volt a legtöbb esetben választott empirikus és célzott szer.

\section{Megbeszélés}

\section{Jelen vizsgálatunk föbb eredményei}

Jelen vizsgálatunk során az összes bevont eset 42,8\%ában igazolódott az influenza A- vagy B-vírus etiológiai szerepe, 7,1\%-ban egyéb légúti vírus jelenlétét mutatták ki. A második leggyakoribb, közösségben szerzett légúti vírus az RSV volt a kohorszban. A komorbiditások és a rizikófaktorok tekintetében a vizsgált alcsoportokban (klinikai ILI/ARI, PCR-pozitív ILI/ARI) hasonló arányok mutatkoztak. Az influenzások körében szerepelt legmagasabb arányban a hospitalizáció, illetve a szociális otthonban való tartózkodás mint rizikófaktor. A komplikált esetekben előforduló leggyakoribb komorbiditás a krónikus szívbetegség és az immunszuppresszió volt. $\mathrm{Az}$ elsődleges kimenetelként megjelölt komplikációk gyakoriságát hasonló nagyságúnak kalkuláltuk az alcsoportokban, a leggyakoribb szövődmény a tüdőgyulladás volt. A viszonylag magas arányban detektált pneumoniák ellenére kevés esetben sikerült a kórfolyamat hátterében bakteriális etiopatogén szerepét igazolni, ami felhívhatja a figyelmet a primer virális pneumonitisek klinikai relevanciájára, valamint az empirikus antimikrobiális terápia megválasztásának és folytatásának átgondolására. Intenzív osztályos felvétel a leggyakrabban a PCR-pozitív, de influenzavírusra nézve negatív betegek körében vált szükségessé, kórházi exitus a klinikai ILI/ARI csoportjában lépett fel. Vizsgálatunk hangsúlyos és egyben sajnálatos megfigyelése volt, hogy - az egyértelmúen fennálló indikációk, az azonosított rizikófaktorok és a hazánkban térítésmentes elérhetőség ellenére - a kohorszba vont egyetlen felnőtt beteg sem részesült szezonális influenza elleni vakcinációban.

\section{A 2018/2019. évi légúti szezon epidemiológiája}

Az ECDC jelentése alapján a 2018/2019. évi légúti szezonban Európában dominálóan az A(H1Nl)pdm09 és A(H3N2) influenza A-szubtípusok cirkuláltak, influenza B-fertózések alacsony számban fordultak elő. A szezon rövidebb volt, mint a 2017/2018-as, de az előző évek átlagaihoz viszonyítva hosszabb ideig tartott. A jelenté- sek alapján a hospitalizációt igénylő esetek száma alacsonyabb volt az előző szezonhoz képest. Az intenzív osztályos ellátás igénye és a betegségspecifikus halálozás a 65 év feletti korosztályt érintette a leginkább, de nem volt elhanyagolható a 40-64 évesek körében sem [8]. Magyarországon a 2018/2019. évi légúti szezonban a Nemzeti Népegészségügyi Központ 1306 betegtől származó klinikai mintát dolgozott fel, ezek közül 545 főnél $(41,7 \%)$ influenza A-vírus - 283 influenza $\mathrm{A}(\mathrm{H} 1 \mathrm{Nl})$ pdm09, 226 influenza $A(\mathrm{H} 3 \mathrm{~N} 2), 36$ influenza $\mathrm{A}(\mathrm{NT})$-, 6 főnél pedig influenza B-vírus okozta fertőzés igazolódott. Ezenfelül 113 fónél RSV-t, 33 betegnél pedig adenovírust mutattak ki [9]. Saját vizsgálati eredményeink tükrözik az európai és a magyar helyzetet a 2018/2019es szezonban.

\section{Más vizsgálatok fóbb eredményei}

Egy korábbi, hasonló vizsgálat a 2015/2016-os és a 2016/2017-es szezonban az ILI jeleit mutató páciensek klinikai karakterisztikáját, illetve a hátterükben álló légúti vírusok kimutatását célozta Franciaországban. 5859 esetből 48,0\%-ban influenzavírus, 7,9\%-ban rhinovirus, 7,5\%-ban RSV, 4,1\%-ban HMPV került kimutatásra. A köhögés influenzával, RSV- és HMPV-fertőzéssel, az orrfolyás rhinovirus-fertőzéssel, míg a fejfájás a leginkább influenzával asszociált, RSV- és HMPV-fertőzés során hiányzott. A szezonális influenza elleni vakcináció csökkentette a klinikailag manifeszt influenza kialakulásának rizikóját [10]. Egy 2018-as, 214 fó bevonásával végzett francia prospektív kohorszvizsgálat légúti tünetetekkel és lázzal, valamint ezek nélküli csoportokban vizsgálta a virális infekciók epidemiológiáját és klinikai karakterisztikáját. A páciensek 34,1\%-ában detektáltak légúti vírust, 7,9\%-ban a bakteriális koinfekció lehetősége is felmerült. A lázas, felső légúti tünetes betegekben a vírusfertőzés incidenciája magasabb volt: ebben a csoportban influenza B-, rhinovirus- és coronavírus-etiológiák fordultak elő gyakrabban, míg a lázat és felső légúti tüneteket nem mutató csoportban parainfluenza és adenovírus okozta fertôzés dominált. A mellkasi diszkomfort jellemzőbb panasz volt igazolt virális fertőzés esetén. A komorbiditások eloszlásában nem volt statisztikailag szignifikáns különbség a csoportok között [11].

Gyermekek körében a kórházi kezelést igénylő legúti fertőzések jelentős kóroki tényezője az RSV. Egy magyar, két légúti szezon (2005/2006 és 2006/2007) adatait feldolgozó tanulmányban - melynek során a 10 év alatti, alsó-felső fertőzéses légúti tüneteket mutató gyermekek garatmosó folyadékait vizsgálták - 104 légúti minta vizsgálatakor 23 mintában $(22,1 \%)$ igazolták az RSV kóroki szerepét. Az RSV-fertőzöttek között a vezető tünet a köhögés (100\%), az orrfolyás (100\%), a légzési nehezítettség (100\%) és a láz $(82,6 \%)$ volt, a fertőzöttek 39,1\%-a rendelkezett hajlamosító alapbetegséggel. Ezen vizsgálat alapján a kórházi ellátást igénylő légúti fertőzések 20\%-ának hátterében RSV állt az adott egész- 
ségügyi intézmény fent megjelölt időszakában. Összehasonlításképpen, a vizsgált 104 gyermek közül csak 2 (1,9\%) fertőzés esetében lehetett kimutatni influenza A-vírust molekuláris módszerrel [12].

ILI miatt hospitalizált betegek körében egy 2016-ban végzett prospektív, multicentrikus vizsgálat az RSV-fertőzések klinikai karakterisztikáját írta le. 1452 hospitalizált páciens közül 59\% volt 65 év feletti, 83\%-uk szenvedett krónikus betegségben. RSV-t 4\%-ban, influenzavírust 39\%-ban igazoltak, kis százalékban a coronavírus, a HMPV, az adenovírus és a humán bocavirus etiológiai szerepe került kimutatásra. Az RSV-fertőzés legfőbb kockázati tényezői ebben a kohorszban az aktív malignitás és az immunszuppresszív kezelés voltak. A kórházi ellátás medián ideje 9 nap volt, az esetek több mint felében szövődmény (pneumonia, akut légzési elégtelenség) jelentkezett. 15\%-ban intenzív osztályos kezelés vált szükségessé, a kórházi mortalitás 8\%-nak adódott [13]. Egy másik vizsgálat eredményei alapján az ILI hajlamosító tényezői a következők voltak: női nem, 14 év alatti életkor, légúti allergia, krónikus betegség jelenléte, túlsúly vagy obesitas, tömegközlekedési eszközök használata, kisállat tartása. A szezonális influenza elleni oltás beadatása ebben a vizsgálatban is protektív faktorként jelent meg [14]. Egy 2012 és 2015 közötti multicentrikus, prospektív vizsgálat a krónikus betegek súlyos lefolyású influenzafertőzésre való rizikóját vizsgálta akut légúti betegség miatt hospitalizált felnőtt betegek körében. Összehasonlítva nem krónikus betegekkel, a súlyos, igazolt influenzafertőzésre való kockázat a leginkább a krónikus szívbetegek, coronariabetegek, végállapotú vesebetegek és COPD-sek körében adódott magasabbnak, a rizikó a korral nőtt [15].

Egy, az influenzához köthető többlethalálozás kimutatását célzó vizsgálatban a 2009/2010 és 2016/2017 között halálozások heti számát modellezték többváltozós idősoros elemzéssel, melyben az influenzaaktivitás és az extrém időjárás szerepelt magyarázó változóként. A halálozás más országok hasonló módszerrel kapott eredményeihez képest azonos nagyságrendúnek, tendenciaszerúen azonban magasabbnak bizonyult. A magasabb átoltottságú országokban a halálozási ráta alacsonyabb volt, így feltehetően Magyarországon is a szezonális átoltottság jelentős növelésére lenne szükség [16].

Egy korábbi vizsgálatban az influenzaasszociált súlyos pneumonia kialakulásának független rizikótényezői a 65 év feletti életkor, a diabetes mellitus és az akut veseelégtelenség, míg a kórkép okozta mortalitás független kockázati tényezői a kevert virális és bakteriális pneumonia, a kórházban szerzett pneumonia, az akut veseelégtelenség és a súlyos tüdőgyulladás voltak. A kevert típusú pneumoniában a leggyakoribb kórokozók a $S$. pneumoniae és a $H$. influenzae voltak [17].

Az influenza elleni vakcináció a leghatékonyabb megelőzési mód, mely egyúttal a súlyos tünetek kialakulását is csökkenti. A szezonális átoltottsági arány mégis ala- csony, az USA-ban a felnőttek átlagosan 41\%-a veszi fel az oltást. A védőoltásokkal szembeni bizalmatlanság mind a lakosság, mind az egészségügyi személyzet körében tapasztalható súlyos probléma. Az orvostanhallgatók vakcinológiai oktatása, tájékozottsága előrelépést jelenthetne a betegeknek az oltások hasznosságáról való meggyőzésében és a megfelelő betegedukációban. A Semmelweis Egyetem orvostanhallgatóinak vakcinológiai ismereteit, védőoltáshoz való hozzáállását mérte fel a Népegészségtan és preventív medicina elnevezésű tantárgy oktatása előtt és után egy 2019-es tanulmány, melyben az influenza elleni védőoltás hasznosságáról, hatékonyságáról szóló előadás is helyet kapott. Az influenza elleni vakcinációt a hallgatók kétharmada tartotta fontosnak. Átoltottságuk az oktatás előtt 6,5\%, az oktatás után $24 \%$ volt, az oktatás és az átoltottság között statisztikailag szignifikáns összefüggés igazolódott [18]. A Debreceni Egyetem Orvos- és Egészségtudományi Centrumában az átoltottságot befolyásoló tényezőket vizsgálták 2010-ben. Az egészségügyi személyzettel 45 kérdésből álló kérdőívet töltettek ki, 524 kiküldött kérdő́ivből 294 értékelhető választ kaptak. Az oltással kapcsolatos döntéshozatalban a munkahelyi belső kommunikáció a legfontosabb eszköz. Az egészségügyi személyzet átoltottsága az intézményi járványok prevenciójában fontos tényező [19]. A járványok kapcsán felmerülő prevenciós feladatok teljesítésében a családorvosok is kulcsszereppel bírnak a lakosságközeli elhelyezkedésükból, szakértelmükből, hozzáállásukból, valamint a páciens körében kivívott bizalomból és személyes példamutatásukból adódóan. A családorvosok segítségével növelhetó a lakosság átoltottságának mértéke és a fertőzéses eredetű betegségek megelőzésének hatékonysága [20].

\section{Korlátok}

Vizsgálatunk eredményeinek általánosíthatóságát limitálja, hogy egycentrumos elrendezésú, a bevont betegek száma viszonylag alacsony, az utánkövetés során pedig korlátozott információtartalomhoz jutottunk hozzá. Centrumunkban az ILI/ARI diagnosztikus és terápiás eljárásrendje nem standardizált, így bizonyos betegek antimikrobiális terápiájának megválasztása, valamint légúti mintájának PCR-vizsgálattal történő vizsgálata a kezelőorvos egyéni döntését reprezentálhatja. Multicentrikus kiterjesztéssel és standardizált betegellátási protokollokkal valószínúleg átfogóbb képet lehetne kapni a hazai ILI-k klinikai és mikrobiológiai karakterisztikájáról.

\section{Következtetés}

Vizsgálatunk során bemutattuk a 2018/2019. évi légúti szezon alatti ILI-k klinikai és mikrobiológiai jellegzetességeit kórházban ellátott felnőtt betegek körében. Az esetek jelentős hányadában influenzavírus állt a panaszok hátterében, melyet gyakoriságban az RSV követett. 
A légúti minták PCR-vizsgálata viszonylag gyors és pontos lehetőséget nyújthat az etiológia tisztázására, különösképpen szövődményes lefolyás esetén.

Anyagi támogatás: SZ. B. G. az EFOP-3.6.3VEKOP-16-2017-00009. számú „Kiegészítő Kutatási Kiválósági Ösztöndíj”-ban és az Innovációs és Technológiai Minisztérium ÚNKP-19-3-I-SE-74. kódszámú Új Nemzeti Kiválóság Programjának szakmai támogatásában részesült. A közlemény megírása, illetve a kapcsolódó irodalmi kutatómunka közvetlen anyagi támogatásban nem részesült.

Szerzôi munkamegosztás: L. B.: Adatgyưjtés, irodalomkutatás, a kézirat szövegezése. Sz. B. G.: Adatértékelés, irodalomkutatás, a kézirat szövegezése, elkészültének szakmai felügyelete.

Érdekeltségek: A szerzőknek a cikk megírásával és megjelenésével kapcsolatban nincsenek érdekeltségeik.

\section{Köszönetnyilvánítás}

A szerzók köszönetet mondanak intézményük klinikusainak, valamint a kémiai, képalkotó és mikrobiológiai laboratóriumi dolgozóknak a magas színvonalú klinikai és diagnosztikus munkájukért.

\section{Irodalom}

[1] Murray CJ, Barber RM, Foreman KJ, et al. Global, regional, and national disability-adjusted life years (DALYs) for 306 diseases and injuries and healthy life expectancy (HALE) for 188 countries, 1990-2013: quantifying the epidemiological transition. Lancet 2015; 386: 2145-2191.

[2] Charlton CL, Babady E, Ginocchio CC, et al. Practical Guidance for Clinical Microbiology Laboratories: viruses causing acute respiratory tract infections. Clin Microbiol Rev. 2018; 32: e0004218.

[3] Luliano AD, Roguski KM, Chang HH, et al. Estimates of global seasonal influenza-associated respiratory mortality: a modelling study. Lancet 2018; 391: 1285-1300.

[4] Egilmezer E, Walker GJ, Bakthavathsalam P, et al. Systematic review of the impact of point of-care testing for influenza on the outcomes of patients with acute respiratory tract infection. Rev Med Virol. 2018; 28: el995.

[5] Carrat F, Sahler C, Rogez S, et al. Influenza burden of illness: estimates from a national prospective survey of household contacts in France. Arch Intern Med. 2002; 162: 1842-1848.

[6] Szúcs T. The socio-economic burden of influenza. J Antimicrob Chemother. 1999; 44(Suppl B): 11-15.

[7] Commission Implementing Decision (EU) 2018/945 of 22 June 2018 on the communicable diseases and related special health issues to be covered by epidemiological surveillance as well as relevant case definitions. Off J Eur Union 2018; 61: 1-74. L170.

[8] European Centre for Disease Prevention and Control. Seasonal influenza, Annual epidemiological report for 2018-2019. Available from: https://www.ecdc.europa.eu/en/publications-data/ seasonal-influenza-annual-epidemiological-report-2018-2019 [accessed: August 1, 2020].

[9] National Public Health and Medical Officer Service. Data on epidemiological surveillance in Hungary, 20th week of 2019. [Nemzeti Népegészségügyi Központ. Tájékoztató az influenza figyelőszolgálat adatairól. Magyarország, 2019. 20. hét - Befejezte múködését az influenza figyelőszolgálat.] Available from: https://www.antsz.hu/felso_menu/temaink/jarvany/influenza/influenza_2019/influ_2019_20.html [accessed: August 1, 2020]. [Hungarian]

[10] Souty C, Masse S, Valette M, et al. Baseline characteristics and clinical symptoms related to respiratory viruses identified among patients presenting with influenza-like illness in primary care. Clin Microbiol Infect. 2019; 25: 1147-1153.

[11] To KK, Chan KH, Ho J, et al. Respiratory virus infection among hospitalized adult patients with or without clinically apparent respiratory infection: a prospective cohort study. Clin Microbiol Infect. 2019; 25: 1539-1545.

[12] Pankovics P, Szabó H, Székely G, et al. Detection and molecular epidemiology of respiratory syncytial virus type A and B strains in childhood respiratory infections in Hungary. [A légúti óriássejtes vírus A és B típusának molekuláris kimutatása és epidemiológiája gyermekkori légúti fertőzésekben.] Orv Hetil. 2009; 150: 121127. [Hungarian]

[13] Loubet P, Lenzi N, Valette M, et al. Clinical characteristics and outcome of respiratory syncytial virus infection among adults hospitalized with influenza-like illness in France. Clin Microbiol Infect. 2017; 23: 253-259.

[14] Guerrisi C, Ecollan M, Souty C, et al. Factors associated with influenza-like illness: a crowdsourced cohort study from 2012/13 to 2017/18. BMC Public Health 2019; 19: 879.

[15] Walker TA, Waite B, Thompson MG, et al. Risk of severe influenza among adults with chronic medical conditions. J Infect Dis. 2020; 221: 183-190.

[16] Kovács K, Pakot L. Influenza-associated mortality in Hungary between 2009/2010 and 2016/2017. [Influenzához kapcsolódó halálozás 2009/2010 és 2016/2017 között Magyarországon.] Orv Hetil. 2020; 161: 962-970. [Hungarian]

[17] Ishiguro T, Kagiyama N, Uozumi R, et al. Clinical characteristics of influenza-associated pneumonia of adults: clinical features and factors contributing to severity and mortality. Yale J Biol Med. 2017; 90: 165-181.

[18] Fehér A, Fekete M, Varga JT, et al. Medical students' knowledge on vaccinology. [Az orvostanhallgatók vakcinológiai tájékozottsága.] Orv Hetil. 2019; 160: 1193-1199. [Hungarian]

[19] Orosi P, Borbély A, Szidor J, et al. Factors affecting influenza vaccine uptake among health care workers at the Medical and Health Sciences Center of Debrecen University, Hungary. [Az influenzaátoltottságot befolyásoló tényezők vizsgálata egészségügyi dolgozók körében a Debreceni Egyetem Orvos- és Egészségtudományi Centrumában.] Orv Hetil. 2012; 153: 505513. [Hungarian]

[20] Hajnal F, Busa Cs, Papp R, et al. The role of primary care professionals in preventive activitites during epidemics. Focus group assessment of the management of flu pandemic in 2009/2010. [Az alapellátásban dolgozó orvosok és munkatársaik preventív szerepe járványok idején. Fókuszcsoportokra alapozott szakmapolitikai hatáselemzés a 2009/2010. évi H1Nl influenzavilágjárvány tapasztalatairól.] Orv Hetil. 2017; 158: 523-532. [Hungarian]

(Szabó Bálint Gergely dr., Budapest, Albert Flórián út 5-7., 11. épület, II. emelet, 202. szoba, 1097 e-mail: szabo.balint.gergely@gmail.com)

A cikk a Creative Commons Attribution 4.0 International License (https://creativecommons.org/licenses/by/4.0/) feltételei szerint publikált Open Access közlemény, melynek szellemében a cikk bármilyen médiumban szabadon felhasználható, megosztható és újraközölhető, feltéve, hogy az eredeti szerző és a közlés helye, illetve a CC License linkje és az esetlegesen végrehajtott módosítások feltüntetésre kerülnek. (SID_1) 